Article

\title{
Effect of Temperature on the Corrosion Behavior of Biodegradable AZ31B Magnesium Alloy in Ringer's Physiological Solution
}

\author{
Sebastian Feliu Jr. ${ }^{1, *}$, Lucien Veleva ${ }^{2}$ and Federico García-Galvan ${ }^{1}$ \\ 1 Surface Engineering, Corrosion and Durability Department, Centro Nacional de Investigaciones \\ Metalúrgicas (CENIM-CSIC), 28040 Madrid, Spain; fedegg82@gmail.com \\ 2 Applied Physics Department, Center for Investigation and Advanced Study (CINVESTAV-IPN), \\ Unidad Merida, 97310 Merida, Mexico; veleva@cinvestav.mx \\ * Correspondence: sfeliu@cenim.csic.es; Tel.: +34-915-538-900
}

Received: 22 April 2019; Accepted: 21 May 2019; Published: 22 May 2019

\begin{abstract}
In this work, the corrosion behaviors of the AZ31B alloy in Ringer's solution at $20^{\circ} \mathrm{C}$ and $37^{\circ} \mathrm{C}$ were compared over four days to better understand the influence of temperature and immersion time on corrosion rate. The corrosion products on the surfaces of the AZ31B alloys were examined by scanning electron microscopy (SEM), energy dispersive X-ray spectroscopy (EDS) and X-ray diffraction (XRD). Electrochemical impedance spectroscopy (EIS) provided information about the protective properties of the corrosion layers. A significant acceleration in corrosion rate with increasing temperature was measured using mass loss and evolved hydrogen methods. This temperature effect was directly related to the changes in chemical composition and thickness of the Al-rich corrosion layer formed on the surface of the AZ31B alloy. At $20^{\circ} \mathrm{C}$, the presence of a thick (micrometer scale) Al-rich corrosion layer on the surface reduced the corrosion rate in Ringer's solution over time. At $37^{\circ} \mathrm{C}$, the incorporation of additional $\mathrm{Mg}$ and $\mathrm{Al}$ compounds containing $\mathrm{Cl}$ into the Al-rich corrosion layer was observed in the early stages of exposure to Ringer's solution. At $37^{\circ} \mathrm{C}$, a significant decrease in the thickness of this corrosion layer was noted after four days.
\end{abstract}

Keywords: magnesium alloys; aluminum; Ringer's solution; hydrogen evolution; corrosion layers; chloride; biomaterials

\section{Introduction}

Magnesium (Mg) alloys are promising biomaterials for degradable implants, because $\mathrm{Mg}$ is biodegradable, non-toxic, and has similar mechanical properties to human bone [1,2]. Among the AZ series (aluminum and zinc), $\mathrm{Mg}$ alloy with 3\% $\mathrm{Al}$ and $1 \% \mathrm{Zn}$ (AZ31) is considered as the first choice for biomedical applications because of its reduced aluminum content, acceptable fatigue resistance, the absence of a significant amount of $\beta$-intermetallic phase on the grain boundary, and good corrosion resistance [1,2]. However, to obtain the most complete information on those factors that influence the degradation process of AZ31 alloys, it should be studied in physiological media.

It is known that an increase in temperature accelerates the corrosion rate of metals [3,4]. In most practical situations, it has been suggested that the corrosion rate doubles for each temperature increase of $10{ }^{\circ} \mathrm{C}$, based on the Arrhenius equation [5-7]. In the specific case of magnesium ( $\mathrm{Mg}$ ) alloys tested in simulated body fluid (SBF), Kirkland et al. [6] reported approximately two-fold increases in corrosion rates for pure $\mathrm{Mg}, \mathrm{Mg}-0.8 \mathrm{Ca}$, and $\mathrm{Mg}-1 \mathrm{Zn}$ in Hank's balanced salt solution (HBSS), between $20^{\circ} \mathrm{C}$ and $37^{\circ} \mathrm{C}$ (physiological temperature of the human body).

However, the temperature dependence of the corrosion rates of $\mathrm{Mg}$ and its alloys immersed in SBF is more complicated, and the microstructure, the presence and quantity of impurities [8] or second 
phases [9], and the differences in their activation with temperature [6] should be considered. Abidin et al. [9] compared the corrosion rates of high-purity Mg and Mg2Zn0.2Mn, ZE41, and AZ91 alloys after their exposure to Hank's solution at $37^{\circ} \mathrm{C}$ against those at room temperature. While the corrosion rates for high-purity $\mathrm{Mg}$ and $\mathrm{Mg} 2 \mathrm{Zn} 0.2 \mathrm{Mn}$ were independent of temperature, the corrosion rates for ZE41 and AZ91 at $37^{\circ} \mathrm{C}$ were $6-9$ times higher than those at room temperature. The accelerated corrosion of ZE41 and AZ91 has been attributed to the presence of microgalvanic cells that form between $\mathrm{Mg}$ and the second-phase precipitates [9], whose electrochemical activity increases with temperature [6]. Since $\mathrm{NaCl}$ is the main component of SBF, the migration and diffusion rates of the aggressive chloride ions are also dependent on temperature [10].

In addition to the accelerating effect of temperature on electrochemical reactions, an increase in temperature from room temperature to $37^{\circ} \mathrm{C}$ can also alter the mechanism of the corrosion process [11,12]. Similar to what has been observed for Ti and Ti-based alloys exposed to Ringer's solution [10], temperature is a critical factor influencing the pitting corrosion of $\mathrm{Mg}$ alloys, since its susceptibility to the development of pits and other forms of localized corrosion increases significantly with temperature $[6,8,13]$.

It is also important to note that the degree of change in corrosion rate with temperature is dependent on the nature and content of alloying elements [6,14]. For pure $\mathrm{Mg}$ and a wide range of $\mathrm{Mg}$ alloys (including $\mathrm{Mg}-\mathrm{Ca}, \mathrm{Mg}-\mathrm{Zn}, \mathrm{Mg}-\mathrm{Mn}, \mathrm{Mg}-\mathrm{Zr}, \mathrm{Mg}-\mathrm{Ca}-\mathrm{Zn}$, and $\mathrm{Mg}-\mathrm{Al}-\mathrm{Zn}$ ) tested in minimum essential medium containing 10\% fetal bovine serum (MEMFBS), Kirkland et al. [6] noted that AZ alloys (Mg-Al-Zn) exhibited much larger increases in corrosion rate with increasing temperature (e.g., $400-500 \%$ for AZ91 and AZ31 alloys) compared with the relatively small increases of $10-100 \%$ for the rest of the $\mathrm{Mg}$ alloys studied and pure $\mathrm{Mg}$. On the other hand, Esmaily et al. [15] observed that during atmospheric corrosion testing, the effect of exposure temperature (ranging from -4 to $22^{\circ} \mathrm{C}$ ) on the corrosion rate of $\mathrm{AZ}$ alloys was directly proportional to the $\mathrm{Al}$ content. Thus, while in the case of $\mathrm{AZ31}(3 \mathrm{wt} \% \mathrm{Al})$, increasing the temperature resulted in a $21 \%$ increase in corrosion rate, the corresponding increase was $92 \%$ for AZ91 (9 wt $\% \mathrm{Al})$. The formation of a very thin Al-enriched inner corrosion layer ( $\sim 9 \mathrm{~nm}$ thick) on the surface of AZ91 at low temperatures $\left(-4\right.$ and $\left.4{ }^{\circ} \mathrm{C}\right)$ blocks the penetration of chloride ions; the breakdown of this layer at $22^{\circ} \mathrm{C}$ plays a crucial role in this temperature effect. The presence of such Al-rich layers on corroded AZ alloys and their influence on the corrosion process is still a contentious issue [16]. Some studies [17-19] have reported $\mathrm{Al}$ enrichment within the corrosion layers formed on $\mathrm{Mg}$ alloys with high $\mathrm{Al}$ content (AZ80 or AZ91), but not in $\mathrm{Mg}-\mathrm{Al}$ alloys with relatively low Al content, such as AZ31 [18,19]. However, other studies have detected such $\mathrm{Al}$ enrichment [20-23] in the corrosion layers formed on AZ31 alloys after exposure to atmospheric conditions or during immersion tests in chloride-containing media [21-23].

The aims of this study were to establish possible relationships between the $\mathrm{Al}$ enrichment in the corrosion layer formed on AZ31B alloy in Ringer's solution and the corrosion rate to better understand the effect of increasing temperature (from $20^{\circ} \mathrm{C}$ to $37^{\circ} \mathrm{C}$ ) on the differences in the chemical and protective characteristics of this layer, and to analyze the influence of temperature of the test solution on the occurrence of pitting corrosion in this alloy.

\section{Materials and Methods}

\subsection{Material Preparation}

Commercially available rolled sheets of AZ31B Mg alloy (Magnesium Elecktron Ltd., Manchester, UK), the composition of which is listed in Table 1, was used in this study. Square coupon specimens with sizes of $20 \times 20 \times 3 \mathrm{~mm}^{3}$ and $50 \times 50 \times 3 \mathrm{~mm}^{3}$ were cut. Prior to testing, the specimens were polished using abrasive $\mathrm{SiC}$ paper up to 2000 grit, finished to a mirror surface with $1 \mu \mathrm{m}$ diamond paste, cleaned in ethanol (Sigma-Aldrich, St. Louis, MO, USA) via bath sonication, and finally dried using compressed air. 
Table 1. Chemical composition (in wt.\%) of AZ31B Mg alloy (X-ray fluorescence analysis).

\begin{tabular}{ccccc}
\hline Element & Mg & Al & Zn & Mn \\
\hline $\mathrm{wt}^{2} \%$ & 95.8 & 3.0 & 1.0 & 0.2 \\
\hline
\end{tabular}

\subsection{Electrolyte Solution}

The electrolyte used for simulating the physiological fluid medium of the human body was Ringer's solution, which was prepared using analytical grade reagents (Sigma-Aldrich, St. Louis, MO, USA) and deionized water with resistivity $18.2 \mathrm{M} \Omega \cdot \mathrm{cm}$. The composition of Ringer's solution was (in $\mathrm{g} / \mathrm{L}$ ) $\mathrm{NaCl}-8.36, \mathrm{KCl}-0.30$, and $\mathrm{CaCl}_{2}-0.15$, and the $\mathrm{pH}$ of the as prepared solution was 6.1 [24]. Experiments were run at temperatures of $20^{\circ} \mathrm{C}$ and $37^{\circ} \mathrm{C}$. The lower temperature was simply room temperature, and was uncontrolled [10]; with temperature accuracy estimated to be $\pm 2{ }^{\circ} \mathrm{C}$. The experiments at the physiological temperature of $37 \pm 1^{\circ} \mathrm{C}$ were controlled using a thermostatic water bath (Ultrasons Medi-II, J.P. Selecta, Barcelona, Spain).

\subsection{Characterization of Corrosion Products}

The surface and cross-sectional morphologies of the corrosion layers were examined by both optical (Olympus BX-51, Olympus, Tokyo, Japan) and scanning electron microscopy (SEM, Jeol JSM 6500F, Jeol Ltd., Tokyo, Japan). The chemical compositions of the corrosion products were analyzed using energy dispersive X-ray spectroscopy (EDS, Oxford Instruments, Oxford, Oxfordshire, UK). Information about the pit geometry was obtained with a 3D microscope using white light interferometry (Leica, DCM8, Leica Micro-systems, Wetzlar, Germany).

Corrosion products on the surface of the AZ31B specimens were analyzed using low-angle X-ray diffraction (XRD, Bruker AXS D8 diffractometer, Bruker AXS, Karlsruhe, Germany) with Cu-K $\alpha$ radiation in the $2 \theta$ range from 10 to $100^{\circ}$ (incidence angle $1^{\circ}$, counting time $4 \mathrm{~s}$ per step, and angular resolution $0.03^{\circ}$ ).

\subsection{Corrosion Rate Measurements}

The corrosion rates of AZ31B alloys were estimated from mass loss and evolved hydrogen measurements. The exposed area was approximately $10.4 \mathrm{~cm}^{2}$, and specimens were immersed in approximately $500 \mathrm{~mL}$ of quiescent Ringer's solution for a period of 4 days at $20^{\circ} \mathrm{C}$ and $37{ }^{\circ} \mathrm{C}$. To measure the volume of the hydrogen gas evolved during the corrosion test, the gas was collected using an inverted burette and funnel setup, where the volume of test solution displaced in the burette was measured. The hydrogen evolution rate, $V_{\mathrm{H}}\left(\mathrm{mL} \mathrm{cm}^{-2} \mathrm{~d}^{-1}\right)$, can be represented as the corrosion rate, $P_{\mathrm{H}}\left(\mathrm{mm} \cdot\right.$ year $\left.^{-1}\right)$, according to Equation (1) [25]:

$$
P_{H}=2.088 \times V_{\mathrm{H}}
$$

After immersion for 1,2 , and 4 days in Ringer's solution at $20^{\circ} \mathrm{C}$ and $37^{\circ} \mathrm{C}$, the corrosion layers formed on the surfaces of the AZ31B specimens were dissolved with an aqueous solution of $200 \mathrm{~g} / \mathrm{L}$ $\mathrm{CrO}_{3}$ (Sigma-Aldrich, St. Louis, MO, USA) and $10 \mathrm{~g} / \mathrm{L} \mathrm{AgNO}_{3}$ (Sigma-Aldrich, St. Louis, MO, USA) for $10 \mathrm{~min}$ prior to weighing the specimens. The immersion tests were performed in triplicate to assess the repeatability of the experimental results.

\subsection{Electrochemical Measurements}

The corrosion behaviors of the AZ31B specimens were assessed by electrochemical impedance spectroscopy (EIS) measurements at open circuit potential (OCP) during immersion in Ringer's solution at $20^{\circ} \mathrm{C}$ and $37^{\circ} \mathrm{C}$. Electrochemical experiments were carried out with an Autolab PGSTAT30 (Metrohm, Herisau, Switzerland) potentiostat/galvanostat. A standard three-electrode cell was used, which consisted of saturated $\mathrm{Ag} / \mathrm{AgCl}$ as the reference electrode (Fisher Scientific Accumet, Waltham, 
MA, USA), a Pt spiral as the counter electrode, and AZ31B Mg alloy as the working electrode (with an exposure area of $9 \mathrm{~cm}^{2}$ ). The spectra were acquired over a frequency range from $100 \mathrm{kHz}$ to $10 \mathrm{mHz}$, using an RMS sinusoidal perturbation of $\pm 10 \mathrm{mV}$ with respect to the OCP. The electrochemical tests were performed in duplicate to ensure reproducibility. ZView software (3.0a Scribner Associates, Inc., Southern Pines, NC, USA) was used to fit the EIS spectra.

\section{Results}

\subsection{Surface and Cross-Sectional Corrosion Product Morphologies}

Figure 1 compares the surface morphologies of the non-exposed AZ31B specimens and those following immersion for 2 and 4 days in Ringer's solution at $20^{\circ} \mathrm{C}$ and $37^{\circ} \mathrm{C}$. A small amount of Al-Mn intermetallic particles was observed for the non-exposed AZ31 specimens (Figure 1a). In contrast to the rather compact and homogeneous corrosion layer formed on the specimens immersed at $20^{\circ} \mathrm{C}$ (Figure $1 \mathrm{~b}, \mathrm{~d}$ ) for 2 and 4 days, and at $37^{\circ} \mathrm{C}$ for 2 days (Figure 1c), a wide pit with a diameter of $\sim 200 \mu \mathrm{m}$ was observed on the surface of the AZ31B specimen immersed for 4 days at $37^{\circ} \mathrm{C}$ (Figure $1 \mathrm{e}$ ).

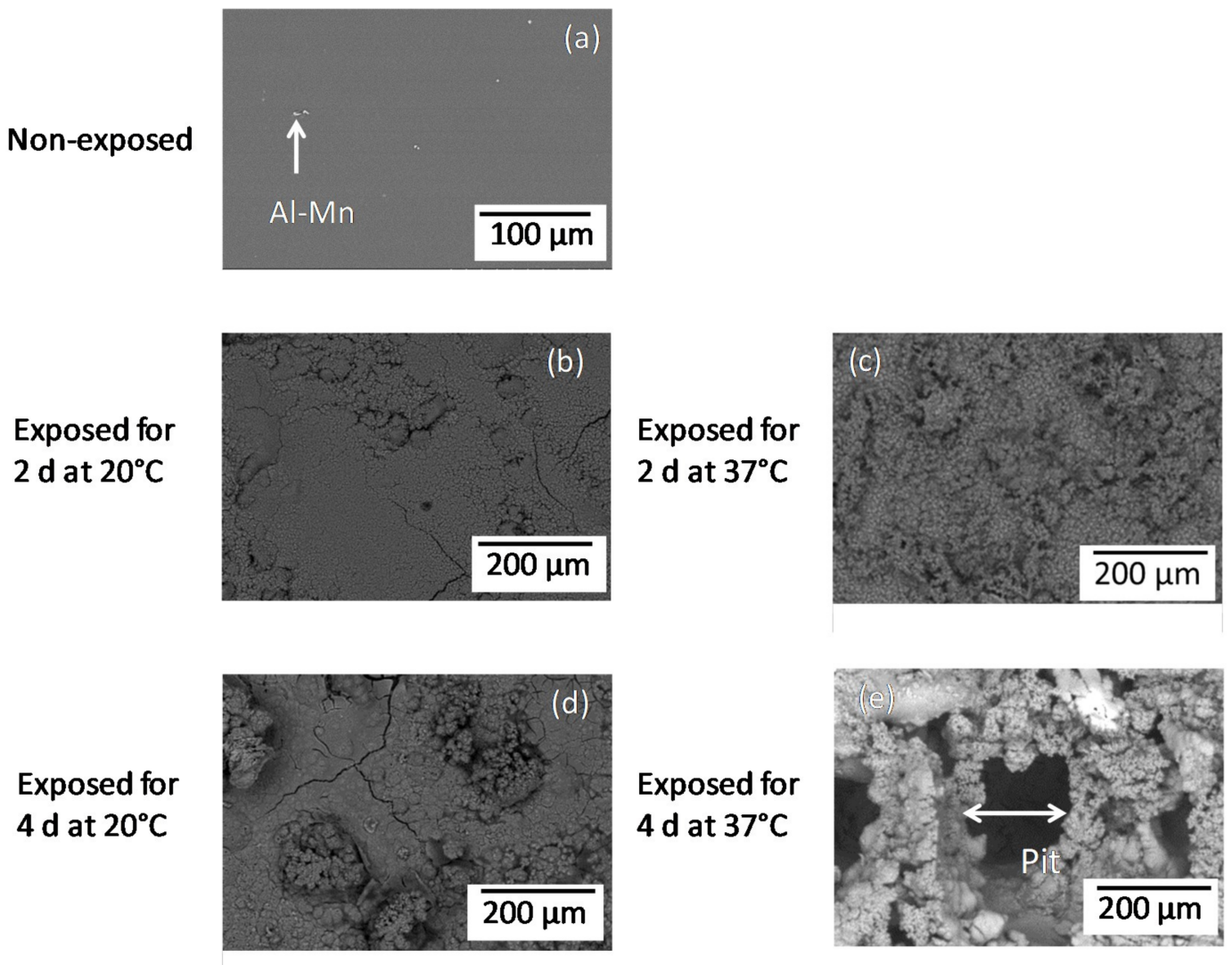

Figure 1. BSE (Back scattered electron) images of AZ31B specimen surfaces non-exposed (a) and immersed in Ringer's solution for 2 days $(\mathbf{b}, \mathbf{c})$ and 4 days $(\mathbf{d}, \mathbf{e})$ at $20^{\circ} \mathrm{C}(\mathbf{b}, \mathbf{d})$ and $37^{\circ} \mathrm{C}(\mathbf{c}, \mathbf{e})$.

The changes in the $\mathrm{Al} /(\mathrm{Al}+\mathrm{Mg})$ at.\% ratios, as measured by EDS, across the corrosion layers formed on the AZ31B specimens following immersion for 2 days and 4 days in Ringer's solution at $20^{\circ} \mathrm{C}$ and $37^{\circ} \mathrm{C}$ are shown in Figures 2 and 3, respectively. No significant difference was noted in the thickness of the Al-rich corrosion layer formed on the surface of the AZ31B specimens over the 4 days immersed at $20{ }^{\circ} \mathrm{C}$ (Figure 2c,d). In contrast, it is interesting to note the significant decrease in the thickness of the Al-rich layer on the corroded AZ31B specimen after 4 days of immersion in Ringer's solution at $37^{\circ} \mathrm{C}$, compared to the value obtained for the specimen immersed for 2 days (Figure 3c,d). 


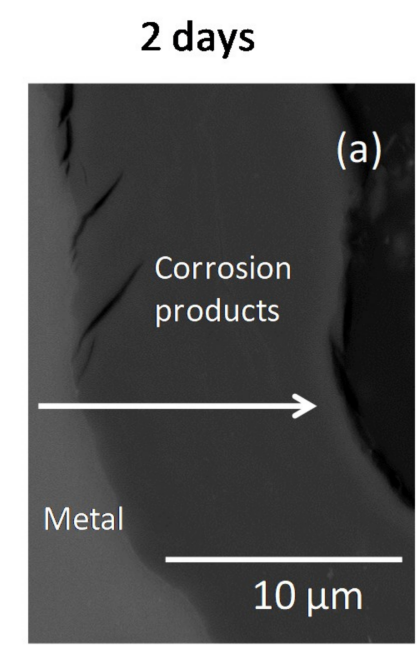

$20^{\circ} \mathrm{C}$
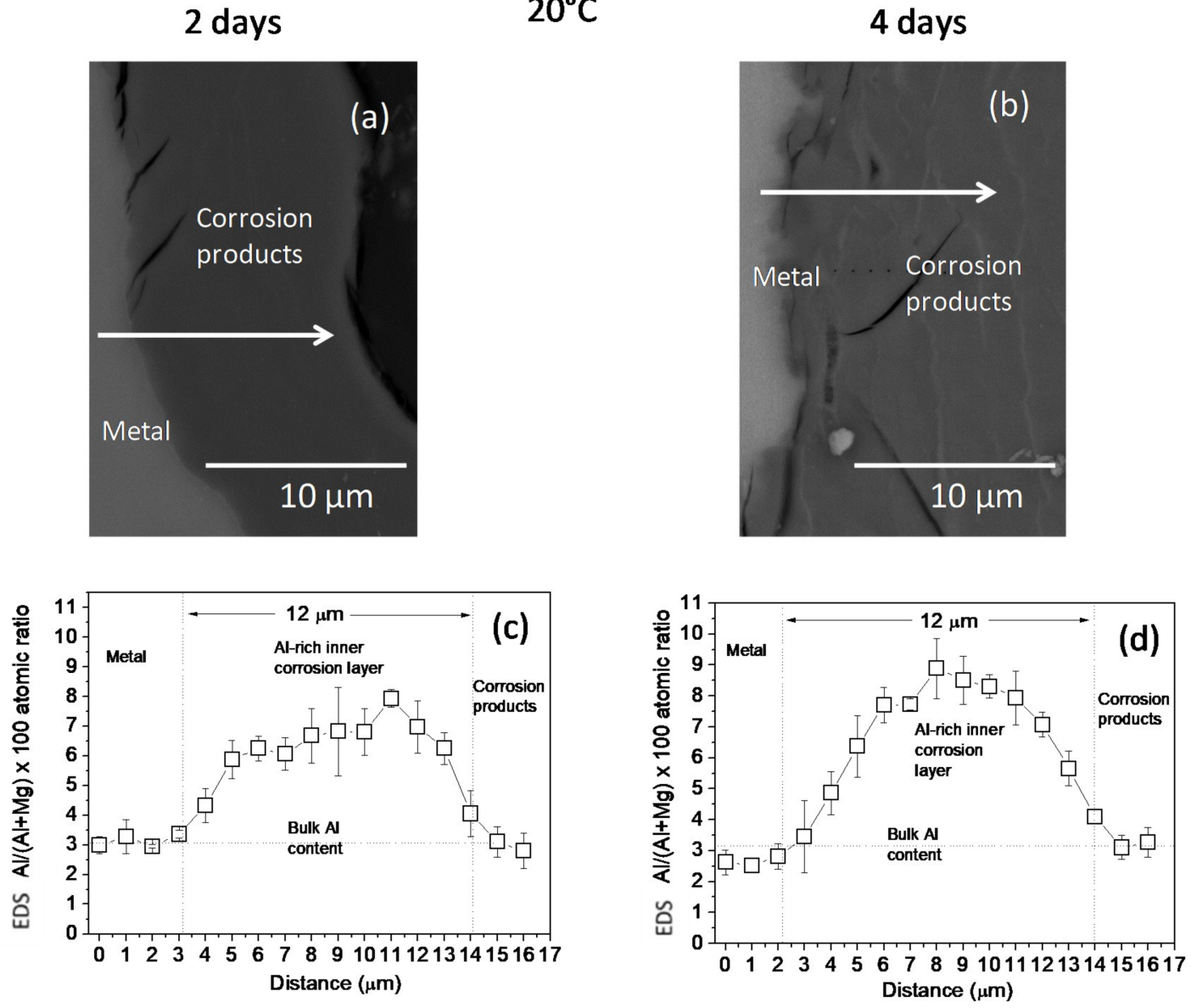

Figure 2. (a,b) BSE images and $(\mathbf{c}, \mathbf{d})$ variations in the $\mathrm{Al} /(\mathrm{Al}+\mathrm{Mg}) \times 100$ atomic ratio with the distance, according to quantitative energy dispersive X-ray spectroscopy (EDS) analysis of cross-sections of corrosion layers formed on AZ31B specimens after immersion in Ringer's solution at $20^{\circ} \mathrm{C}$ for $(\mathbf{a}, \mathbf{c}) 2$ days and (b,d) 4 days. Scatter bands shown in (c,d) represent the standard deviation of 3 measurements. 


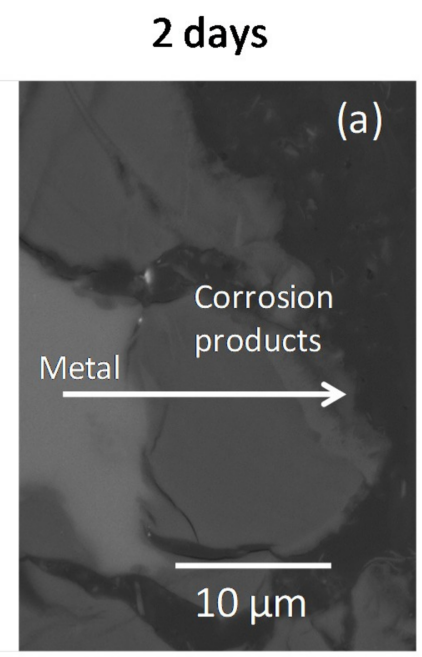

$37^{\circ} \mathrm{C}$

4 days
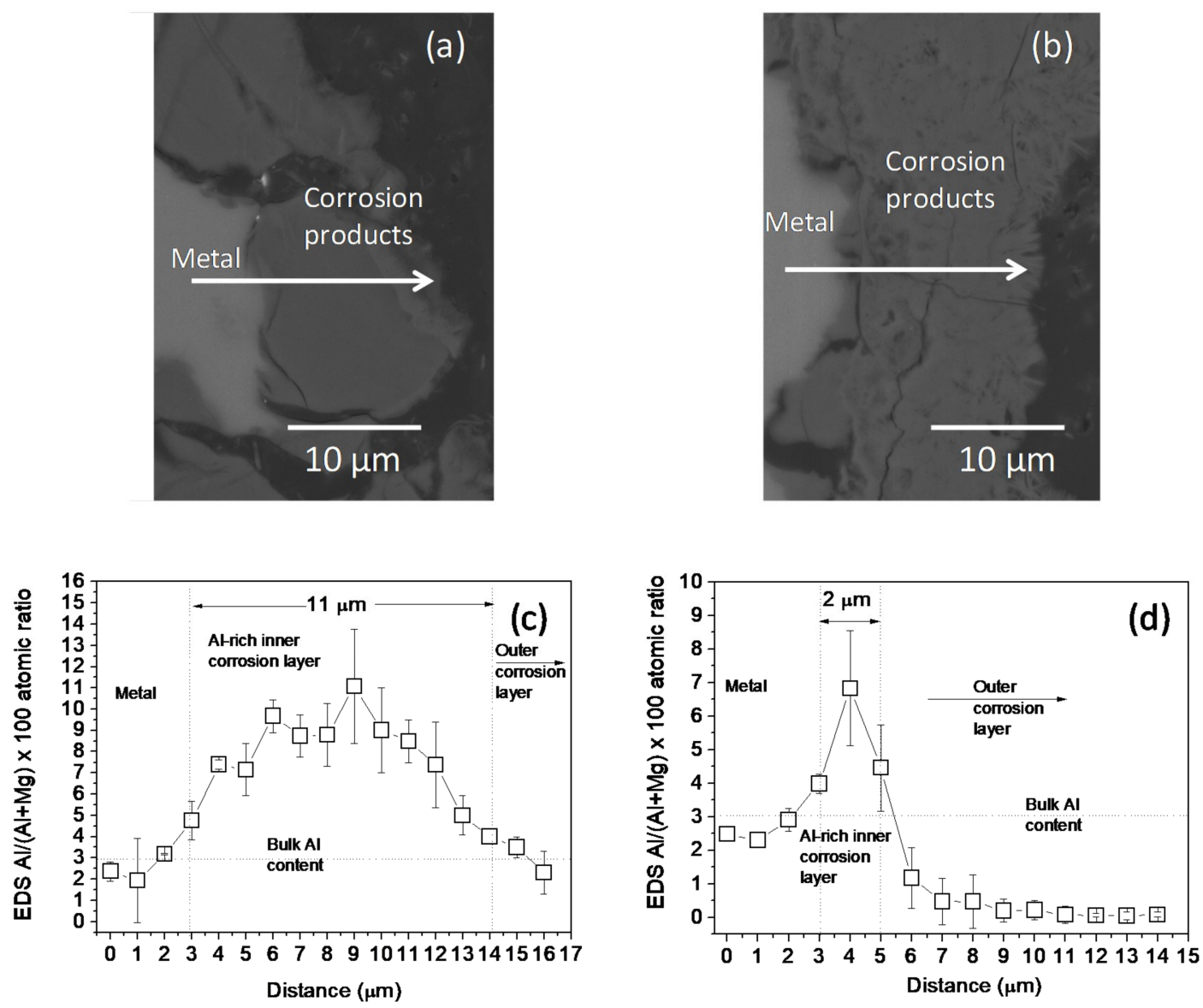

Figure 3. (a,b) BSE images and $(\mathbf{c}, \mathbf{d})$ variations in the $\mathrm{Al} /(\mathrm{Al}+\mathrm{Mg}) \times 100$ atomic ratio with the distance, according to quantitative EDS analysis of cross-sections of corrosion layers formed on AZ31B specimens after immersion in Ringer's solution at $37^{\circ} \mathrm{C}$ for $(\mathbf{a}, \mathbf{c}) 2$ days and $(\mathbf{b}, \mathbf{d}) 4$ days. Scatter bands shown in $(\mathbf{c}, \mathbf{d})$ represent the standard deviation of 3 measurements.

The average atomic compositions of the corrosion layers formed on the surfaces of AZ31B specimens immersed in Ringer's solution for 2 days at $20^{\circ} \mathrm{C}$ and $37^{\circ} \mathrm{C}$, obtained by cross-sectional EDS analysis, are shown in Table 2. These analyses revealed a significant reduction in the atomic percentage of oxygen in the corrosion product layer, along with a significant $\mathrm{Cl}$ content (approximately 8 at.\%), in the specimens immersed at $37^{\circ} \mathrm{C}$ in comparison to the values obtained for the specimens immersed at $20^{\circ} \mathrm{C}$. These changes with temperature could suggest some degree of replacement of the oxygen-containing corrosion products by chloride species in the corrosion layers formed on the AZ31B specimens in Ringer's solution.

Table 2. EDS atomic composition of cross-sections of corrosion layers formed on AZ31B specimens after immersion for 2 days in Ringer's solution at $20^{\circ} \mathrm{C}$ and $37^{\circ} \mathrm{C}$. Average values from 10 spectra are shown.

\begin{tabular}{cccccc}
\hline Exposure Temperature & O (at.\%) & Mg (at.\%) & Al (at.\%) & Cl (at.\%) & Zn (at.\%) \\
\hline $20^{\circ} \mathrm{C}$ & $64 \pm 4$ & $33 \pm 4$ & $2.3 \pm 0.2$ & $0.0 \pm 0.1$ & $0.2 \pm 0.2$ \\
$37^{\circ} \mathrm{C}$ & $47 \pm 2$ & $39 \pm 3$ & $4.2 \pm 0.6$ & $8.1 \pm 1$ & $1.8 \pm 0.4$ \\
\hline
\end{tabular}


The cross-sectional morphology, the $\mathrm{Al} /(\mathrm{Al}+\mathrm{Mg})$ at.\% ratios, and the $\mathrm{Cl}$ at.\% obtained by $\mathrm{EDS}$ microanalysis across a pit formed on the AZ31B specimen after immersion for 4 days in Ringer's solution at $37^{\circ} \mathrm{C}$ are presented in Figure $4 \mathrm{a}-\mathrm{C}$, respectively. The analysis revealed that $\mathrm{Cl}$ and $\mathrm{Al}$ were enriched in the pit (Figure $4 \mathrm{~b}, \mathrm{c})$. The similar composition gradients of $\mathrm{Cl}$ content and $\mathrm{Al} /(\mathrm{Al}+\mathrm{Mg})$ at. \% ratios obtained by EDS point analysis across the corrosion pit (Figure $4 \mathrm{~b}, \mathrm{c}$ ) may be suggestive of some association of chloride with the Al.
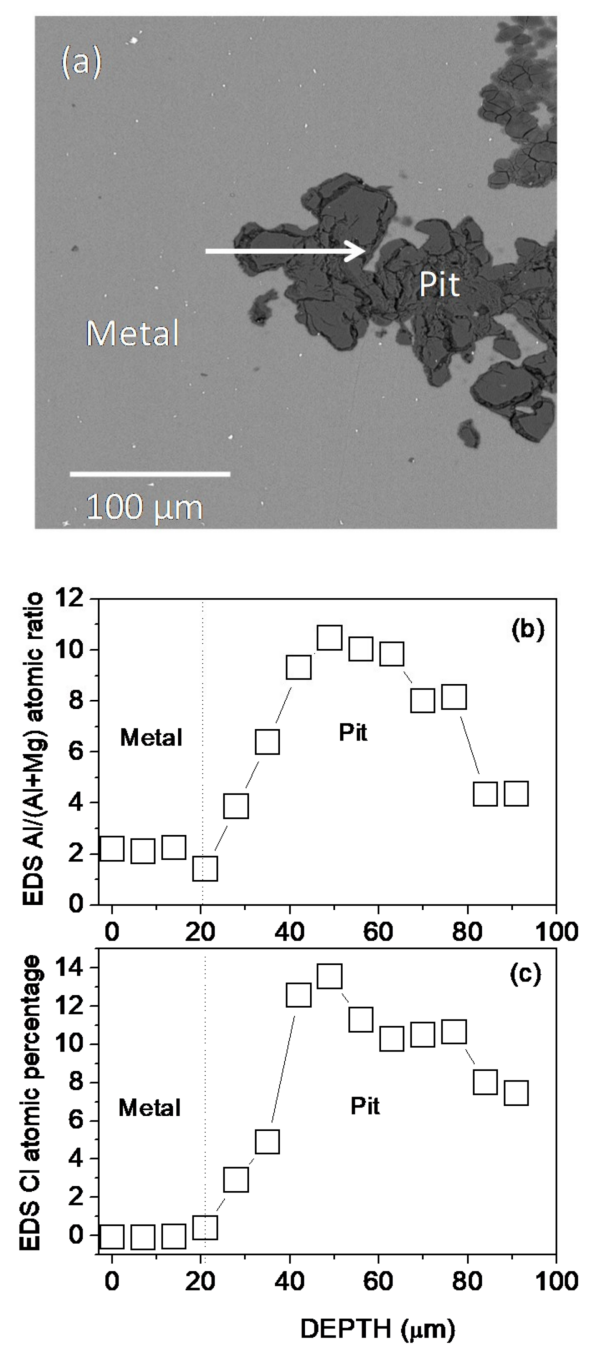

Figure 4. (a) BSE image of the cross-section of a pit formed on the AZ31B specimen after immersion in Ringer's solution at $37^{\circ} \mathrm{C}$ for $4 \mathrm{~d}$. (b) Variations in (b) the $\mathrm{Al} /(\mathrm{Al}+\mathrm{Mg}) \times 100$ atomic ratio and (c) $\mathrm{Cl}$ atomic percentage with the distance according to quantitative EDS analysis.

Figure 5 shows a comparison between optical microscopy images of cross-sections of the deepest corrosion pits for the AZ31B specimens immersed in Ringer's solution for 4 days at $20^{\circ} \mathrm{C}$ and $37^{\circ} \mathrm{C}$. The increase in temperature led to very deep pitting corrosion (Figure $5 \mathrm{~b}$ ), to depths up to $912 \mu \mathrm{m}$, while at $20^{\circ} \mathrm{C}$ this localized attack was less extensive $(\approx 154 \mu \mathrm{m})$ (Figure $5 \mathrm{a}$ ). 


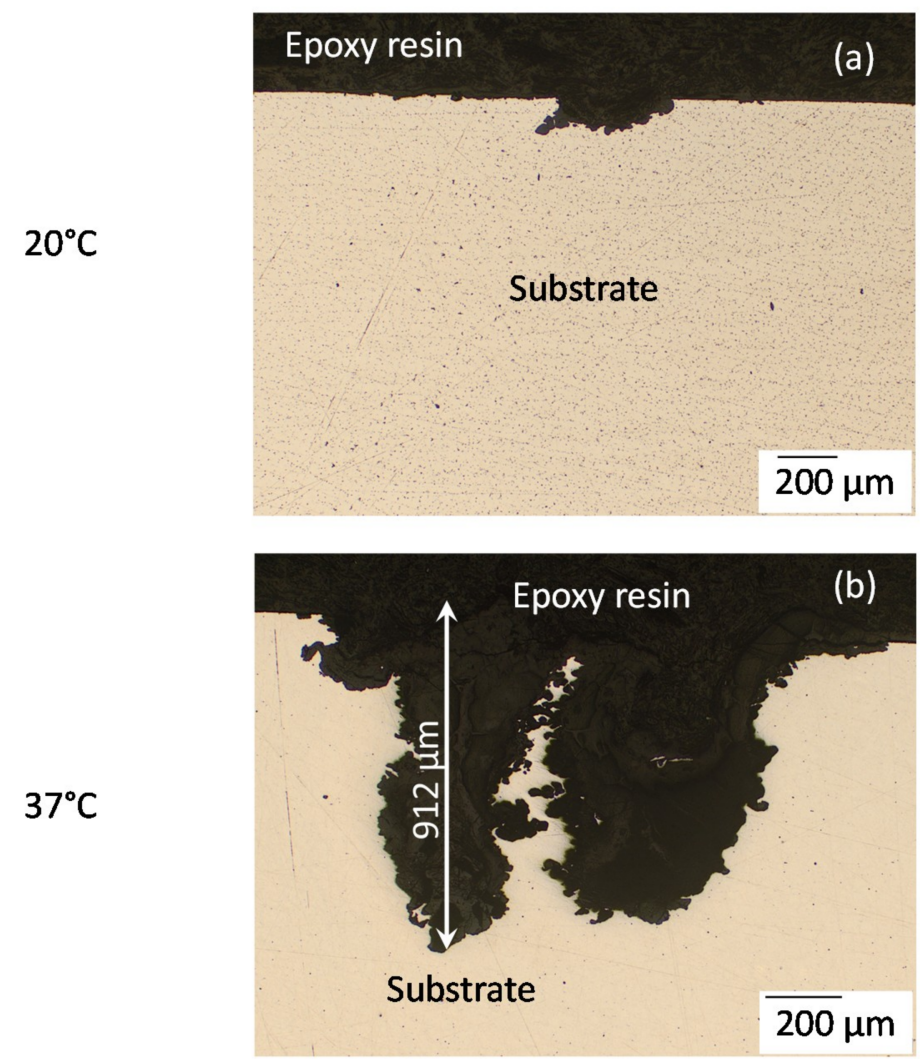

Figure 5. Optical microscopy images of cross-sections of AZ31B specimens after immersion in Ringer's solution for 4 days: at $20^{\circ} \mathrm{C}$ (a) and (b) at $37^{\circ} \mathrm{C}$.

The 3D images in Figure 6 present the pit morphology of the AZ31B specimens immersed in Ringer's solution for 4 days at $20^{\circ} \mathrm{C}$ and $37^{\circ} \mathrm{C}$, after removal of the corrosion products. It can be seen that the depth and width of the pits formed at $37^{\circ} \mathrm{C}$ are significantly greater (Figure 6b) than those formed at $20^{\circ} \mathrm{C}$ (Figure 6a). The average depths and widths of the corrosion pits are given in Table 3 . After immersion in Ringer's solution for 4 days, the AZ31B specimens immersed at $37^{\circ} \mathrm{C}$ had wider and deeper pits than those formed after immersion at $20^{\circ} \mathrm{C}$. 

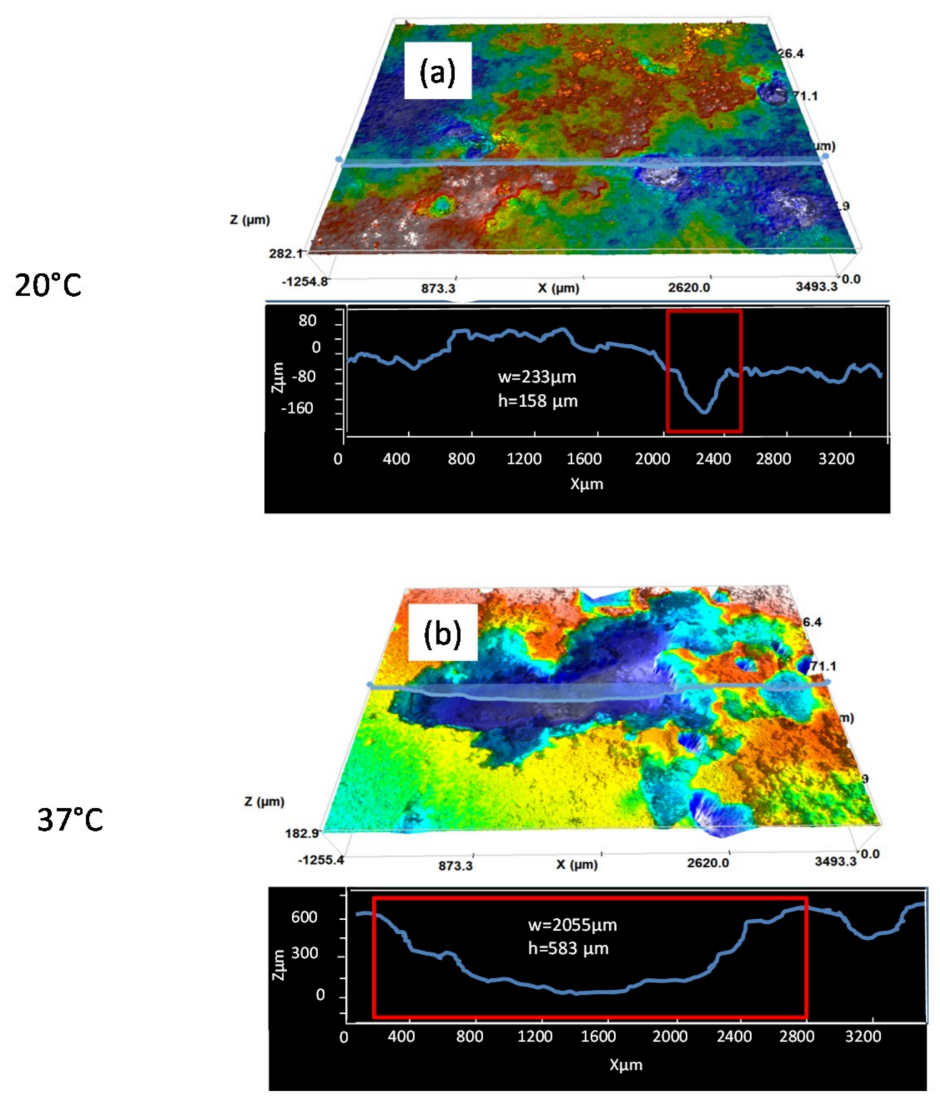

Figure 6. 3D analysis of pits in AZ31B specimen surfaces immersed in Ringer's solution for 4 days, after removal of the corrosion products: at (a) $20^{\circ} \mathrm{C}$ and (b) $37^{\circ} \mathrm{C}$.

Table 3. Average size of corrosion pits formed in AZ31B specimen surfaces after immersion in Ringer's solution for 4 days at $20^{\circ} \mathrm{C}$ and $37^{\circ} \mathrm{C}$. Average values from 4 different areas are shown.

\begin{tabular}{ccc}
\hline Temperature & Average Pit Depth $(\mu \mathrm{m})$ & Average Pit Width $(\mu \mathrm{m})$ \\
\hline $20^{\circ} \mathrm{C}$ & $105 \pm 57$ & $256 \pm 45$ \\
$37^{\circ} \mathrm{C}$ & $470 \pm 325$ & $1857 \pm 405$ \\
\hline
\end{tabular}

\subsection{XRD Analysis}

Figure 7 shows low-angle XRD patterns of the AZ31B specimens after immersion in Ringer's solution at $20^{\circ} \mathrm{C}$ and $37^{\circ} \mathrm{C}$ for 2 days and 4 days. The spectra revealed that the corrosion product layer mainly consisted of $\mathrm{Mg}(\mathrm{OH})_{2}$. Significant metallic Mg-peaks were only detected in the XRD spectrum of AZ31B specimens immersed in Ringer's solution for 2 days at $20^{\circ} \mathrm{C}$, because of the thinner corrosion layer, compared to those of the specimens immersed at $37^{\circ} \mathrm{C}$. 


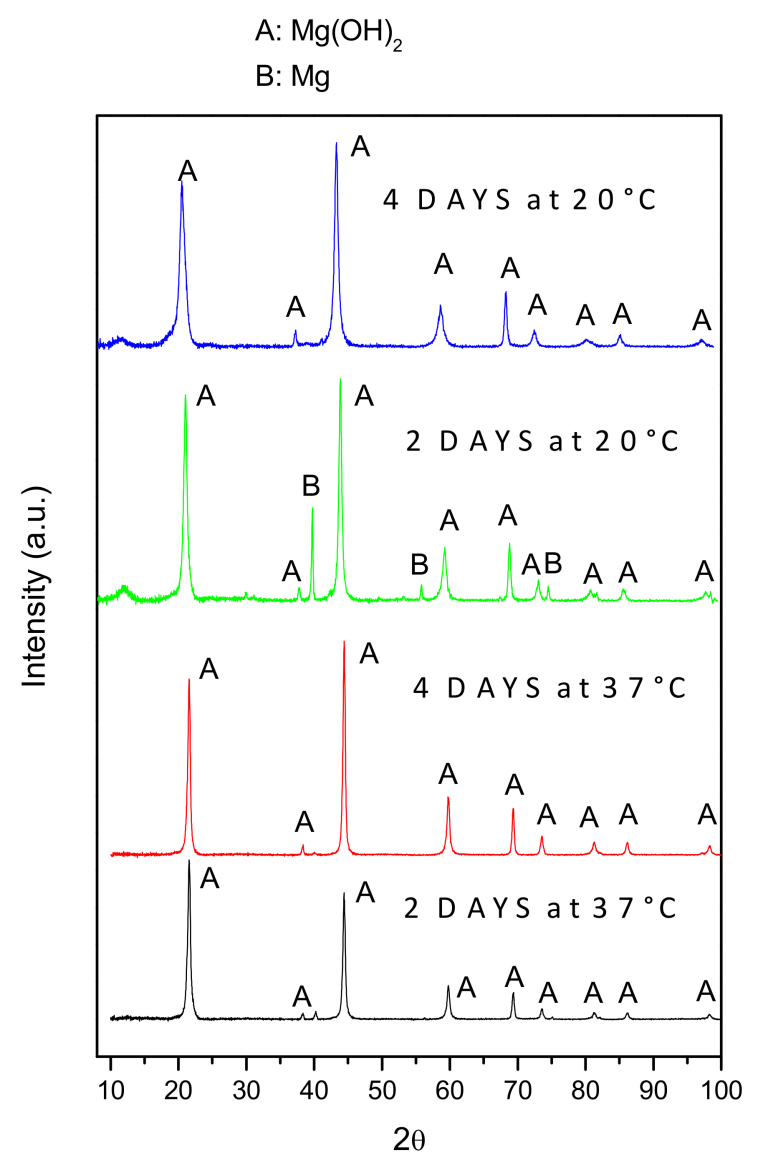

Figure 7. Low-angle XRD patterns of AZ31B specimens after immersion in Ringer's solution at $20^{\circ} \mathrm{C}$ and $37^{\circ} \mathrm{C}$, for 2 days and 4 days.

\subsection{Hydrogen Evolution and Mass Loss Measurements}

Figure 8 presents the differences in hydrogen evolution between the AZ31B specimens immersed for 4 days in Ringer's solution at $20^{\circ} \mathrm{C}$ and $37^{\circ} \mathrm{C}$. The results indicate that hydrogen evolution volume from the AZ31B specimens increased almost linearly over time when immersed at $20^{\circ} \mathrm{C}$, while at $37^{\circ} \mathrm{C}$ there was a tendency to increase exponentially with immersion time (Figure 8a).

Figure $8 \mathrm{~b}$ shows the corrosion rate, $P_{\mathrm{H}}$, calculated from the hydrogen evolution data (Figure $8 \mathrm{a}$ ) and the immersion times using Equation (1). After 1 day of immersion at $20^{\circ} \mathrm{C}$, the AZ31B specimen showed a low corrosion rate, which remained essentially constant over the whole immersion period. In contrast, the corrosion rate of the specimen immersed at $37^{\circ} \mathrm{C}$ continually increased over 4 days, and the final corrosion rate was approximately four times higher than that of the specimen immersed at $20^{\circ} \mathrm{C}$ (Figure $8 \mathbf{b}$ ).

Figure 9 shows the changes in corrosion rates, as determined from mass loss measurements, with increasing immersion time in Ringer's solution at $20^{\circ} \mathrm{C}$ and $37^{\circ} \mathrm{C}$. The corrosion rates at $37^{\circ} \mathrm{C}$ were approximately 2.5 and 4 times higher after the first and fourth days of immersion, respectively, than those at $20^{\circ} \mathrm{C}$. It should be noted that a similar trend was determined from the hydrogen evolution data (Figure 8b). 


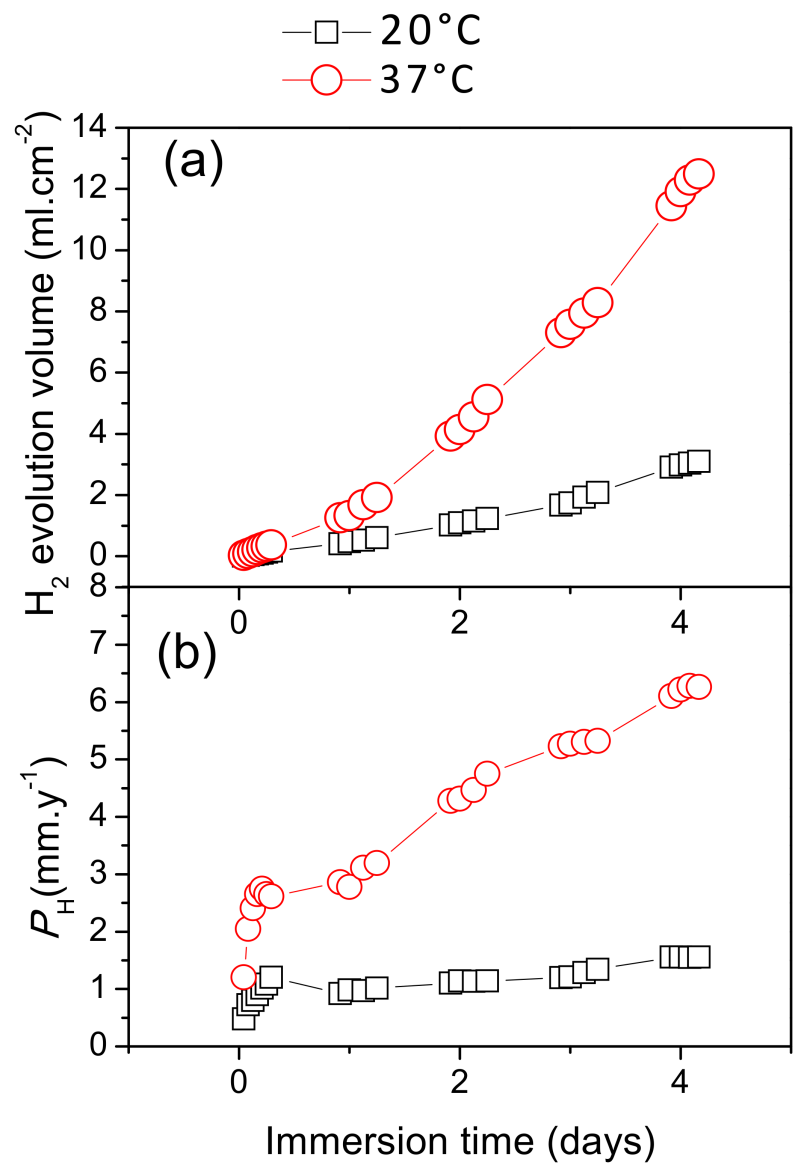

Figure 8. Variations in corrosion of AZ31B specimens over 4 days of immersion in Ringer's solution, as a function of temperature: (a) Hydrogen evolution volume; (b) corresponding corrosion rates, $P_{\mathrm{H}}$.

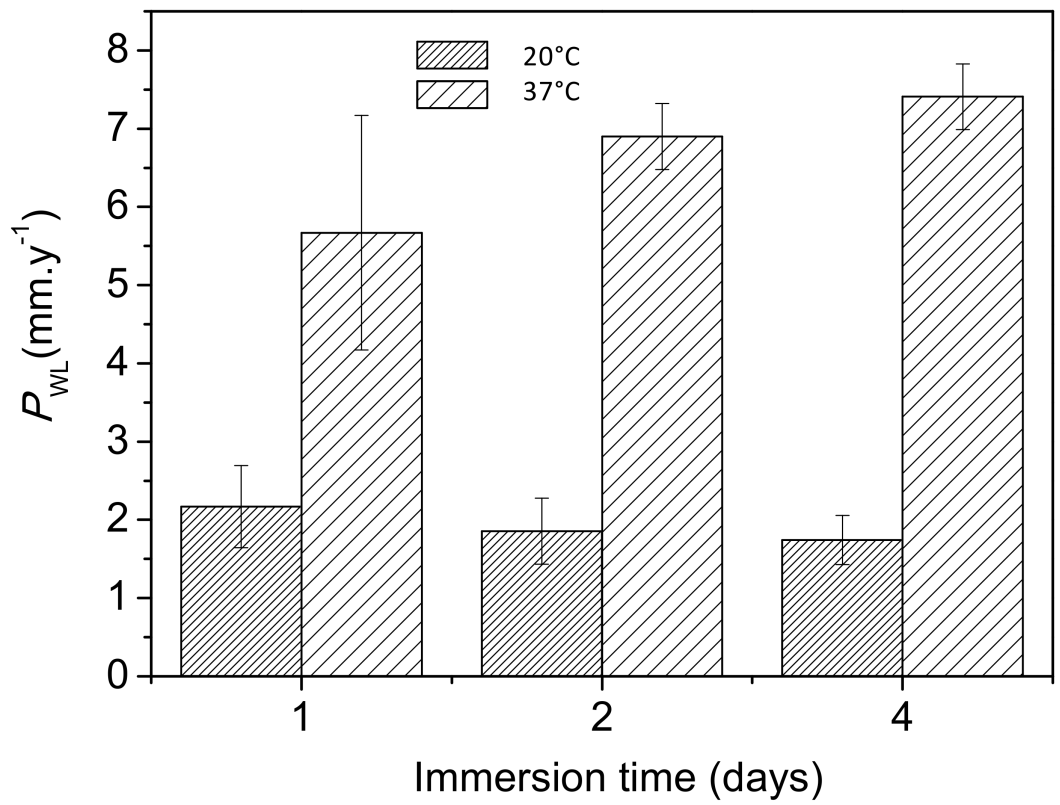

Figure 9. Variations in corrosion rates $\left(\mathrm{mm} \cdot \mathrm{y}^{-1}\right)$ of AZ31B specimens as a function of temperature over 4 days of immersion in Ringer's solution, obtained from mass loss measurements. 


\subsection{EIS Diagrams}

Figure 10 compares the Nyquist plots obtained for the AZ31B specimens immersed in Ringer's solution at $20{ }^{\circ} \mathrm{C}$ with those at $37^{\circ} \mathrm{C}$, for several exposure times up to 4 days. All diagrams exhibited a capacitive loop at high frequencies (HF), the diameters of which became smaller with increasing immersion time. An inductive loop was observed at low frequencies. For the AZ31B specimens immersed at $37^{\circ} \mathrm{C}$, the size of the inductive loop decreased markedly (Figure 10), which may be as a consequence of diminished thickness of the Al-rich inner corrosion layer with immersion time (Figure 3). In contrast, there was no appreciable change in the size of the inductive loop for the AZ31B specimens immersed at $20^{\circ} \mathrm{C}$ (Figure 10), when the thickness of the Al-rich inner corrosion layer remained constant over 4 days (Figure 2). These relationships suggest an influence of the composition and the thickness of formed corrosion layers on AZ31 surfaces on the degree of the inductive EIS response. A similar effect was reported in our previous study [26].

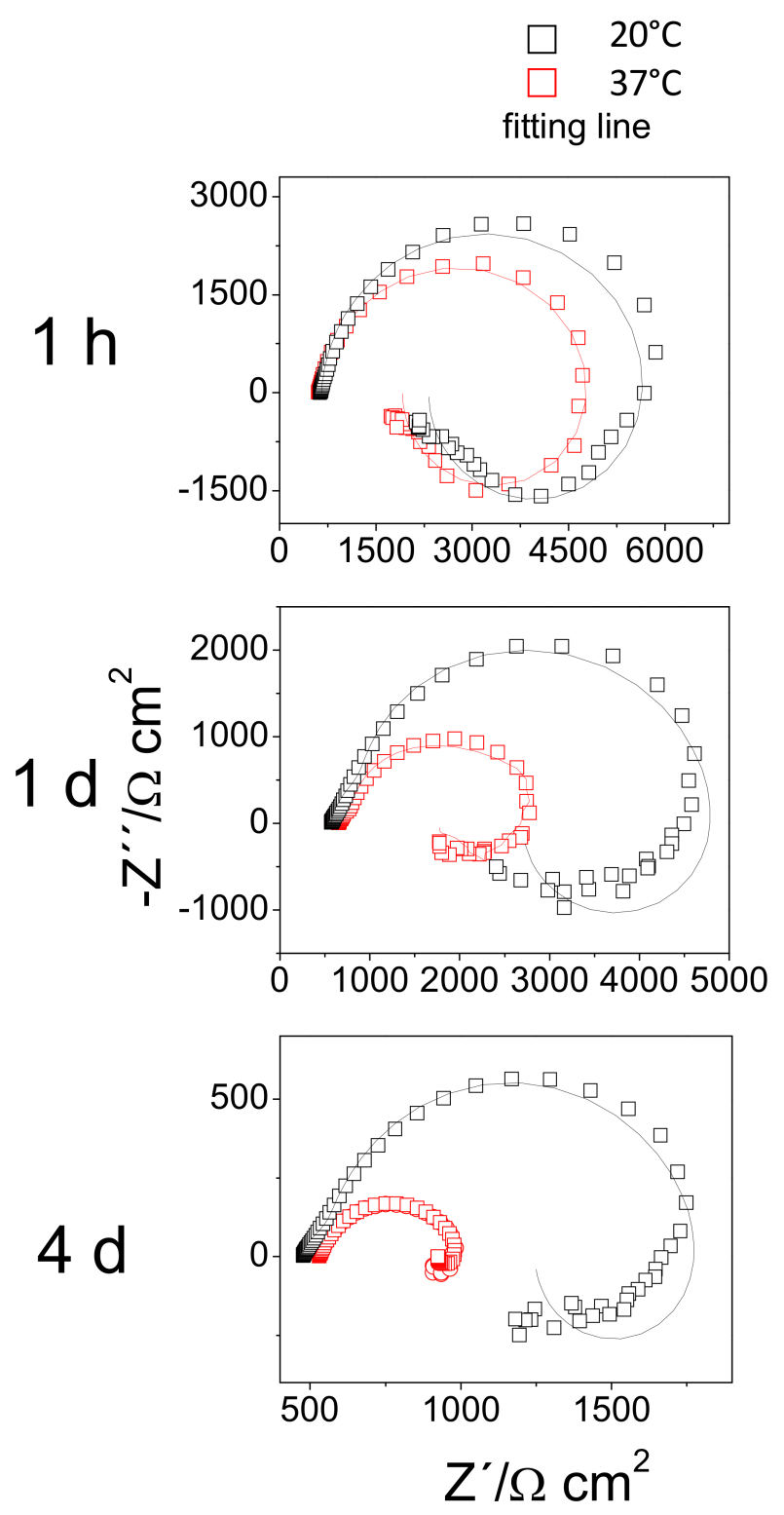

Figure 10. Nyquist plots of AZ31B specimens immersed for $1 \mathrm{~h}, 1$ day, and 4 days in Ringer's solution at $20^{\circ} \mathrm{C}$ and $37^{\circ} \mathrm{C}$. 
The EIS plots (Figure 10) were fitted with the electrical equivalent circuit (EEC), shown in Figure 11, which gave satisfactory results in our previous studies $[23,26] . R_{\mathrm{s}}$ corresponds to the electrolyte resistance, $R_{\mathrm{t}}$ is the charge transfer resistance, $C P E_{1}$ is a constant phase element associated with the electrical double layer, $L$ is the inductor, and $R_{1}$ is the resistance of the inductive response.

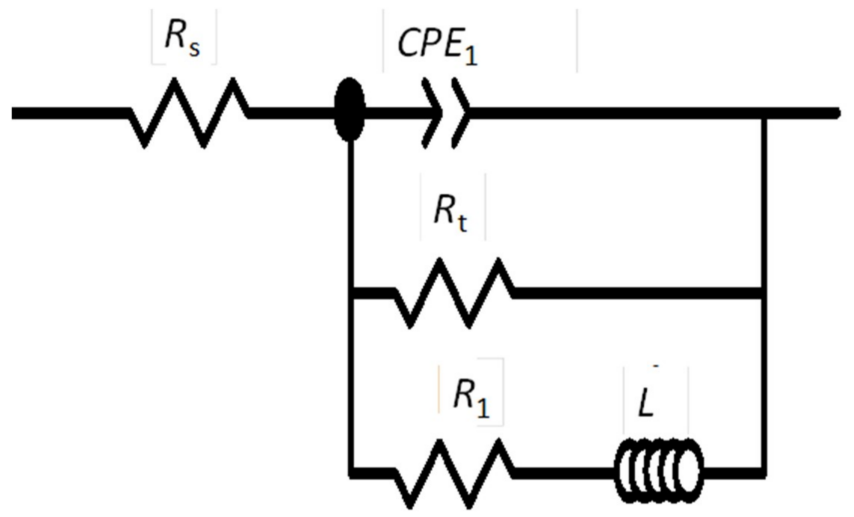

Figure 11. The equivalent circuit used for fitting experimental electrochemical impedance spectroscopy (EIS) plots of AZ31B specimens immersed in Ringer's solution at $20^{\circ} \mathrm{C}$ and $37^{\circ} \mathrm{C}$.

Figure 12 shows the change in the fitted values of $R_{\mathrm{t}}$ with immersion time. After the first day of immersion, the $R_{\mathrm{t}}$ values of the AZ31B specimens immersed at $20^{\circ} \mathrm{C}$ were approximately two or three times greater than those of the specimens immersed at $37^{\circ} \mathrm{C}$. The differences between the hydrogen volume data (Figure $8 \mathrm{~b}$ ) and $R_{\mathrm{t}}$ measurements (Figure 12) may be related to the different configuration of the exposed surface area of the specimens. For the hydrogen evolution measurements (used for the calculation rate of the corrosion process), square coupon specimens were entirely exposed to the aggressive solution and their edges (active areas) were not protected. However, for the electrochemical measurements of $R_{\mathrm{t}}$, the exposed area was confined by means of a circular gasket, which protects the edges.

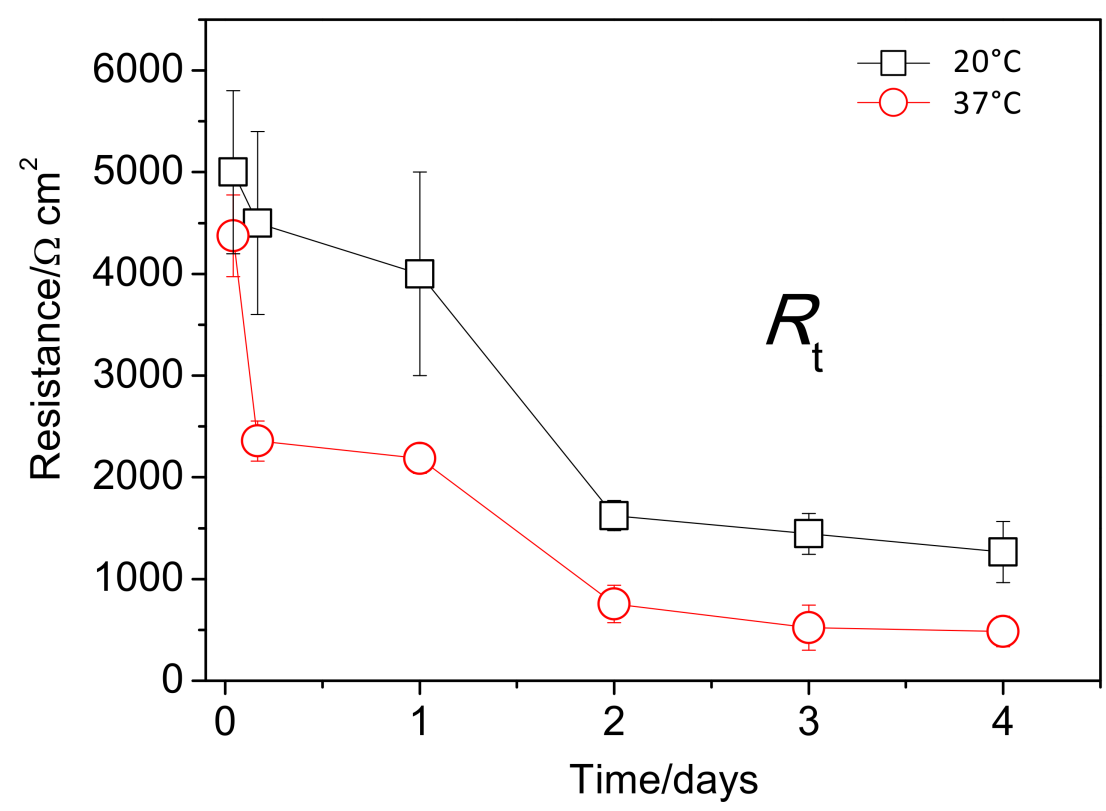

Figure 12. Variations in charge transfer resistance $\left(R_{\mathrm{t}}\right)$ values as a function of immersion time, obtained from fitting of the EIS plots of AZ31B specimens immersed in Ringer's solution at $20^{\circ} \mathrm{C}$ and $37^{\circ} \mathrm{C}$. 


\section{Discussion}

4.1. Influence of Temperature on the Composition and Thickness of the Al-Rich Corrosion Layer Formed on the Surface of the Az31b Alloy in Ringer's Solution

The XRD spectra (Figure 7) indicated that $\mathrm{Mg}(\mathrm{OH})_{2}$ was the main corrosion product formed on the surfaces of the AZ31B specimens immersed in Ringer's solution. When immersed in an aqueous $\mathrm{NaCl}$ solution, it is generally accepted that the anodic dissolution of $\mathrm{Mg}$ and the cathodic evolution of hydrogen occur according to Equations (2) and (3) [27-29]:

$$
\begin{gathered}
\text { Anodic reaction : } \mathrm{Mg} \rightarrow \mathrm{Mg}^{2+}+2 \mathrm{e}^{-} \\
\text {Cathodic reaction : } 2 \mathrm{H}_{2} \mathrm{O}+2 \mathrm{e}^{-} \rightarrow 2 \mathrm{OH}^{-}+\mathrm{H}_{2} \uparrow
\end{gathered}
$$

The overall reaction can be expressed as:

$$
\mathrm{Mg}+2 \mathrm{H}_{2} \mathrm{O} \rightarrow \mathrm{Mg}(\mathrm{OH})_{2}+\mathrm{H}_{2} \uparrow
$$

The significant increase in the $\mathrm{Cl}$ atomic percentage with increasing temperature, as observed by EDS (Table 2), in the corrosion layers formed after 2 days of immersion in Ringer's solution may be related to the enhanced migration of chloride ions toward the metal/oxide interface at higher temperatures $[10,13,30]$. Similar chloride enrichment with temperature has been noted in the corrosion layers formed on AZ91 Mg alloy [15] and 2A02 Al alloy [30] during their atmospheric exposure in the presence of $\mathrm{NaCl}$. The enrichment of chlorine in the corrosion layer is expected to enhance the conversion of the $\mathrm{Mg}(\mathrm{OH})_{2}$ corrosion product to soluble $\mathrm{MgCl}_{2}$, according to Equation (5):

$$
\mathrm{Mg}(\mathrm{OH})_{2}+2 \mathrm{Cl}^{-} \rightarrow \mathrm{MgCl}_{2}+2 \mathrm{OH}^{-}
$$

In addition to the accumulation of $\mathrm{MgCl}_{2}$ species, the interaction between $\mathrm{Al}$ enriched corrosion products on the $\mathrm{AZ31B}$ alloy [22,23] and $\mathrm{Cl}^{-}$ions may generate $\mathrm{AlCl}_{3}$ compounds, according to Equation (6) [30]:

$$
\mathrm{Al}(\mathrm{OH})_{3}+3 \mathrm{Cl}^{-} \rightarrow \mathrm{AlCl}_{3}+3 \mathrm{OH}^{-}
$$

Accordingly, significant evidence of the presence of aluminum chloride salts was observed in the EDS point analysis of the corrosion products inside the pits on the AZ31B specimen immersed in Ringer's solution at $37^{\circ} \mathrm{C}$ for 4 days (Figure 4 b,c). Similarly, in a previous work [26] investigating the same alloy in Ringer's solution, significant amounts of aluminum oxychloride salts were found in the uniform corrosion layer after immersion for 2 days.

There have been previous reports on the formation of metal chlorides on magnesium alloys in contact with aqueous saline solutions whose growth at the metal/oxide interface resulted in the mechanical rupture of the corrosion layer [31,32] as a result of its greater molar volume [10,31]. In this study, the significant decrease in the thickness of the Al-rich layer observed on the AZ31B alloy immersed at $37^{\circ} \mathrm{C}$ for 4 days (Figure 3) might be attributed to the breakdown and loss of this layer, which could be enhanced by the presence of chloride salts.

\subsection{Relationship Between Corrosion Resistance and the Characteristics of the Al-Rich Inner Corrosion Layer}

The hydrogen evolution volume over time (Figure 8), mass loss data (Figure 9), and EIS results (Figures 10 and 12), provide complementary information about the influence of the composition/thickness of the Al-rich inner corrosion layer on the corrosion behavior of the AZ31B alloy surface in Ringer's solution.

After 1 day of immersion, the hydrogen evolution and mass loss data obtained for AZ31B alloy immersed in Ringer's solution at $37^{\circ} \mathrm{C}$ (Figures $8 \mathrm{~b}$ and 9) revealed that the corrosion rate increased continuously throughout the immersion period, suggesting a progressive deterioration of the Al-rich 
inner corrosion layer. Further, the intensification of pitting corrosion in the specimen immersed at the higher temperature (Figures 5 and 6) may be associated with the deterioration of this corrosion layer and the enhanced migration of $\mathrm{Cl}^{-}$ions towards the anodic sites. These observations agree with the important reduction in thickness of the Al-rich inner corrosion layer formed on AZ31B alloy surfaces immersed at $37^{\circ} \mathrm{C}$ for 4 days, as was revealed by EDS (Figure 3c,d). These results agree with previous findings of Esmaily et al. [15,16], regarding the temperature dependence of the corrosion rate of the AZ91D alloy under atmospheric conditions.

In contrast to the corrosion rates of the AZ31B specimens tested at $37^{\circ} \mathrm{C}$ in Ringer's solution, those rates corresponding to $20{ }^{\circ} \mathrm{C}$ (Figures $8 \mathrm{~b}$ and 9) remained unchanged over time and were much lower. SEM observations and EDS analysis (Figure 2) revealed significant Al enrichment in the corrosion layers formed on AZ31B alloy surfaces exposed over 4 days at $20^{\circ} \mathrm{C}$. These data suggest that the formation of the Al-rich inner corrosion layer on AZ31B alloy surfaces in Ringer's solution may keep the development of corrosion at a lower level. This is consistent with previously reported results $[18,19,23]$, which suggested that the presence of an Al-rich inner corrosion layer on $\mathrm{Mg}-\mathrm{Al}$ alloys improves their corrosion resistance in corrosive media. Based on the present findings, it would seem that the approach of selecting alloying elements to self-produce enriched inner corrosion layers with enhanced barrier properties in contact with the different corrosive environments is a possible solution to improve intrinsic corrosion resistance of $\mathrm{Mg}$ alloys.

\section{Conclusions}

A four-fold increase in the corrosion rate of AZ31B alloy immersed in Ringer's solution at $37^{\circ} \mathrm{C}$ was measured, compared to that at $20^{\circ} \mathrm{C}$. Variations in the thickness and composition of the Al-rich inner corrosion layers, formed at both temperatures with immersion time, may reasonably explain the acceleration of the corrosion rate. The EDS data showed that the Al-rich inner corrosion layer on the AZ31B alloy exposed to Ringer's solution at $20{ }^{\circ} \mathrm{C}$ retained its chemical composition and physical characteristics throughout the exposure to Ringer's solution. The analysis of mass loss and hydrogen evolution data revealed that the Al-rich inner corrosion layer may act as an effective barrier, blocking the penetration of aggressive $\mathrm{Cl}^{-}$ions and as well as improving the corrosion resistance of the AZ31B alloy. EDS analysis revealed a considerable chloride enrichment in the Al-rich inner corrosion layer on AZ31B alloy surface immersed in Ringer's solution at $37^{\circ} \mathrm{C}$ for 2 days. The formation of $\mathrm{Mg}$ and $\mathrm{Al}$ compounds containing chloride was closely associated with a significant reduction in the thickness of the Al-rich inner corrosion layer and the corresponding reduction of its protective properties. The decrease in the thickness of the Al-rich inner corrosion layer formed on the surface of the AZ31B alloy after 4 days immersed at $37^{\circ} \mathrm{C}$ coincided with the intensification in pitting corrosion.

Author Contributions: F.G.-G. performed the preparation of samples and their corrosion tests. L.V. and S.F. discussed the results and wrote the manuscript with contributions from all authors. L.V. and S.F. conceived and supervised the project. All correspondence should be addressed to S.F.

Funding: This research was funded by the Spanish Ministry of Economy and Competitiveness (project MAT2015-65445-C2-1-R).

Conflicts of Interest: The authors declare no conflict of interest.

\section{References}

1. Saikrishna, N.; Reddy, G.P.K.; Munirathinam, B.; Sunil, B.R. Influence of bimodal grain size distribution on the corrosion behavior of friction stir processed biodegradable AZ31 magnesium alloy. J. Magn. Alloys. 2016, 4, 68-76. [CrossRef]

2. Song, Y.; Shan, D.; Chen, R.; Zhang, F.; Han, E.-H. Biodegradable behaviors of AZ31 magnesium alloy in simulated body fluid. Mater. Sci. Eng. C 2009, 29, 1039-1045. [CrossRef]

3. LeBozec, N.; Jonsson, M.; Thierry, D. Atmospheric corrosion of magnesium alloys: Influence of temperature, relative humidity, and chloride deposition. Corrosion 2004, 60, 356-361. [CrossRef] 
4. Merino, M.C.; Pardo, A.; Arrabal, R.; Merino, S.; Casajus, P.; Mohedano, M. Influence of chloride ion concentration and temperature on the corrosion of $\mathrm{Mg}-\mathrm{Al}$ alloys in salt fog. Corros. Sci. 2010, 52, 1696-1704. [CrossRef]

5. Melchers, R.E. Effect of temperature on the marine immersion corrosion of carbon steels. Corrosion 2002, 58, 768-782. [CrossRef]

6. Kirkland, N.T.; Birbilis, N. Magnesium Biomaterials: Design, Testing, and Best Practice; Springer New York: New York, NY, USA, 2014; pp. 40-43.

7. Cai, Y.K.; Zhao, Y.; Ma, X.B.; Zhou, K.; Chen, Y. Influence of environmental factors on atmospheric corrosion in dynamic environment. Corros. Sci. 2018, 137, 163-175. [CrossRef]

8. Song, G.L.; Atrens, A. Corrosion mechanisms of magnesium alloys. Adv. Eng. Mater. 1999, 1, 11-33. [CrossRef]

9. Abidin, N.I.Z.; Atrens, A.D.; Martin, D.; Atrens, A. Corrosion of high purity Mg, Mg2Zn0.2Mn, ZE41 and AZ91 in Hank's solution at $37^{\circ} \mathrm{C}$. Corros. Sci. 2011, 53, 3542-3556. [CrossRef]

10. Burstein, G.T.; Liu, C.; Souto, R.M. The effect of temperature on the nucleation of corrosion pits on titanium in Ringer's physiological solution. Biomaterials 2005, 26, 245-256. [CrossRef]

11. Virtanen, S.; Milosev, I.; Gomez-Barrena, E.; Trebse, R.; Salo, J.; Konttinen, Y.T. Special modes of corrosion under physiological and simulated physiological conditions. Acta Biomater. 2008, 4, 468-476. [CrossRef]

12. Bauer, S.; Schmuki, P.; von der Mark, K.; Park, J. Engineering biocompatible implant surfaces Part I: Materials and surfaces. Prog. Mater. Sci. 2013, 58, 261-326. [CrossRef]

13. Frankel, G.S. Pitting corrosion of metals a review of the critical factors. J. Electrochem. Soc. 1998, 145, 2186-2198. [CrossRef]

14. Kirkland, N.T.; Lespagnol, J.; Birbilis, N.; Staiger, M.P. A survey of bio-corrosion rates of magnesium alloys. Corros. Sci. 2010, 52, 287-291. [CrossRef]

15. Esmaily, M.; Blucher, D.B.; Svensson, J.E.; Halvarsson, M.; Johansson, L.G. New insights into the corrosion of magnesium alloys-the role of aluminum. Scripta Mater. 2016, 115, 91-95. [CrossRef]

16. Esmaily, M.; Svensson, J.E.; Fajardo, S.; Birbilis, N.; Frankel, G.S.; Virtanen, S.; Arrabal, R.; Thomas, S.; Johansson, L.G. Fundamentals and advances in magnesium alloy corrosion. Prog. Mater. Sci. 2017, 89, 92-193. [CrossRef]

17. Phillips, R.C.; Kish, J.R. Nature of Surface Film on Matrix Phase of Mg Alloy AZ80 Formed in Water. Corrosion 2013, 69, 813-820. [CrossRef]

18. Pardo, A.; Merino, M.C.; Coy, A.E.; Arrabal, R.; Viejo, F.; Matykina, E. Corrosion behavior of magnesium/aluminum alloys in 3.5wt.\% NaCl. Corros. Sci. 2008, 50, 823-834. [CrossRef]

19. Nordlien, J.H.; Nisancioglu, K.; Ono, S.; Masuko, N. Morphology and Structure of Oxide Films Formed on $\mathrm{MgAl}$ Alloys by Exposure to Air and Water. J. Electrochem. Soc. 1996, 143, 2564-2572. [CrossRef]

20. Cui, Z.Y.; Ge, F.; Lin, Y.; Wang, L.W.; Lei, L.; Tian, H.Y.; Yu, M.D.; Wang, X. Corrosion behavior of AZ31 magnesium alloy in the chloride solution containing ammonium nitrate. Electrochim. Acta 2018, 278, 421-437. [CrossRef]

21. Jang, Y.; Collins, B.; Sankar, J.; Yun, Y. Effect of biologically relevant ions on the corrosion products formed on alloy AZ31B: An improved understanding of magnesium corrosion. Acta Biomater. 2013, 9, 8761-8770. [CrossRef]

22. Liao, J.S.; Hotta, M. Corrosion products of field-exposed Mg-Al series magnesium alloys. Corros. Sci. 2016, 112, 276-288. [CrossRef]

23. Delgado, M.G.; Garcia-Galvan, F.R.; Llorente, I.; Perez, P.; Adeva, P.; Feliu Jr, S. Influence of aluminum enrichment in the near-surface region of commercial twin-roll cast AZ31 alloys on their corrosion behavior. Corros. Sci. 2017, 123, 182-196. [CrossRef]

24. ISO 16428, Implants for Surgery-Test Solutions and Environmental Conditions for Static and Dynamic Corrosion Tests on Implantable Materials and Medical Devices. 2005. Available online: https://www.iso.org/ standard/30280.html (accessed on 5 April 2019).

25. Johnston, S.; Shi, Z.M.; Dargusch, M.S.; Atrens, A. Influence of surface condition on the corrosion of ultra-high-purity Mg alloy wire. Corros. Sci. 2016, 108, 66-75. [CrossRef]

26. Veleva, L.; Fernandez-Olaya, M.G.; Feliu, S. Initial stages of AZ31B magnesium alloy degradation in ringer's solution: Interpretation of EIS, mass loss, hydrogen evolution data and scanning electron microscopy observations. Metals 2018, 8, 933. [CrossRef] 
27. Song, G.; Song, S. A possible biodegradable magnesium implant material. Adv. Eng. Mater. 2007, 9, $298-302$. [CrossRef]

28. Witte, F.; Hort, N.; Vogt, C.; Cohen, S.; Kainer, K.U.; Willumeit, R.; Feyerabend, F. Degradable biomaterials based on magnesium corrosion. Curr. Opin. Solid State Mater. Sci. 2008, 2, 63-72. [CrossRef]

29. Song, G.; Atrens, A. Understanding magnesium corrosion-A framework for improved alloy performance. Adv. Eng. Mater. 2003, 5, 837-858. [CrossRef]

30. Cao, M.; Liu, L.; Fan, L.; Yu, Z.F.; Li, Y.; Oguzie, E.E.; Wang, F.H. Influence of Temperature on Corrosion Behavior of 2A02 Al Alloy in Marine Atmospheric Environments. Materials 2018, 11, 235. [CrossRef]

31. Kish, J.R.; Hu, Y.; Li, J.; Zheng, W.; McDermid, J.R. Technical note: Examination of focused ion beam-sectioned surface films formed on AM60 B Mg alloy in an aqueous saline solution. Corrosion 2012, 68, 468-474. [CrossRef]

32. Grogan, J.A.; Leen, S.B.; McHugh, P.E. A physical corrosion model for bioabsorbable metal stents. Acta Biomater. 2014, 10, 2313-2322. [CrossRef]

(C) 2019 by the authors. Licensee MDPI, Basel, Switzerland. This article is an open access article distributed under the terms and conditions of the Creative Commons Attribution (CC BY) license (http://creativecommons.org/licenses/by/4.0/). 